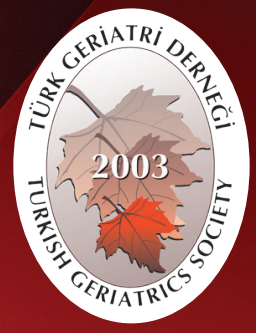

Turkish Journal of Geriatrics

DOI: 10.31086/tigeri.2018240418

2018:21 (2):173-183

- Mehmet ARSLAN ${ }^{1}$

- Esra MELTEM KOÇ²

- Melih Kaan SÖZMEN ${ }^{3}$

\title{
THE TURKISH ADAPTATION OF THE TILBURG FRAILTY INDICATOR: A VALIDITY AND RELIABILITY STUDY
}

\section{Abstract}

Introduction: Frailty is a dynamic condition that affects individuals who suffer from loss in one or more areas of human functioning (physical, psychological, and social). It is possible to reduce morbidity and mortality by recognizing this condition in the elderly. This study aimed to develop a Turkish adaptation of the Tilburg Frailty Indicator and assess whether it is a valid, reliable tool for the Turkish population.

Materials and Method: Our descriptive cross-sectional study enrolled 271 individuals aged $>65$ years. The scale was adapted into Turkish before conducting the study. Known groups were tested using confirmatory factor analysis to assess the validity of the scale. The Cronbach's alpha reliability and the Kuder-Richardson Formula-21 internal consistency coefficients were used to assess the reliability.

Results: The median age of the participants was 71 years (range $=65-90$ years). The average total frailty score was $4.56 \pm 3.09$. The total Cronbach's alpha coefficient for the Tilburg Frailty Indicator was 0.758 . The Kuder-Richardson Formula-21 reliability coefficient was 0.758 for the entire scale. The summary of good agreement findings obtained by confirmatory factor analysis showed that the scale can conceptually define the construct it was designed to measure at a good level.

Conclusion: Based on our results, it has been established that the Turkish adaptation of the Tilburg Frailty Indicator is a valid and reliable tool. We believe that our findings have contributed to early detection of problems related to elderly health and the management of frailty in primary care.

Keywords: Reproducibility of results; Frail elderly; Aging; Turkey

ARAŞTIRMA

CORRESPONDANCE

Mehmet ARSLAN

Narlıdere Health Directorate, İzmir, Turkey

Phone: 05384779970

Fax: 02322387126

e-mail: mehmt.arslann@gmail.com

Received: $26 / 12 / 2017$

Accepted: $02 / 05 / 2018$

Narlıdere Health Directorate, İzmir, Turkey

Izmir Katip Çelebi University, Faculty of

Medicine, Department of Family Medicine

İzmir, Turkey

3 İzmir Katip Çelebi University, Faculty of

Medicine, Department of Public Health,

Izmir, Turkey

The study has been presented in "gth Family Medicine Research Days" as an oral presentation on 11 Nov 2016 in Aydın.

\section{TILBURG KIRILGANLIK ÖLÇEĞI'NIN TÜRKÇEYE UYARLANMASI: GEÇERLIK VE GÜVENIRLIK ÇALIŞMASI}

$\ddot{O}_{z}$

Giriş: Kırılganlık, bir veya daha fazla alanda (fiziksel, psikolojik, sosyal) fonksiyon kaybına bağlı, yaşlıları etkileyen dinamik bir durumdur. Bu yaşlılar tanınarak gerekli koruyucu ve tedavi edici önlemlerin alınması sayesinde morbitede ve mortalite değerlerini azaltılabilir. Bu araştırmanın ana amacı yaşlılarda kırılganlığı değerlendirmek için kullanılan bir araç olan Tilburg Kırılganlık Ölçeği'ni Türkçeye uyarlayarak, Türk toplumu için geçerli güvenilir bir araç olup olmadığını incelemektir.

Gereç ve Yöntem: Çalışmanın evrenini 65 yaşüstü 271 kişi oluşturdu. Çalışmaya başlamadan önce Tilburg Kırılganlık Ölçeği, Türkçeye uyarlandı. Ölçeğin geçerliği için doğrulayıcı faktör analizi ile bilinen gruplar sınaması yapıldı. Güvenirlik için Cronbach alfa güvenirlik katsayısı ve Kuder \& Richardson-21 iç tutarlılık katsayısı değerlendirildi.

Bulgular: Bireylerin ortanca yaş değeri 71 ( $\min =65, \max =90$ )'dir. Katılımcıların kırılganlık skor ortalaması $4.56 \pm 3.09$ olarak tespit edildi. TKÖ için Cronbach alfa total ölçümü 0.758 olarak hesaplanmıştır. Alt boyutlarda elde edilen Kuder \& Richardson-21 güvenirlik katsayısı ölçeğin bütünü için 0.758 olarak belirlenmiştir. Doğrulayıcı faktör analizi ile elde edilen özet uyum iyiliği bulguları, ölçeğin kavramsal olarak ölçmek istediği yapıyı iyi bir düzeyde tanımlayabildiğini göstermektedir.

Sonuç: Araştırmanın sonuçlarına göre, Tilburg Kırılganlık Ölçeğinin ülkemiz için geçerli ve güvenilir bir araç olduğu ortaya konmuştur. Tilburg Kırılganlık Ölçeği'ni Türkçeye uyarlayarak, yaşlı sağlığı ile ilgili problemlerin erken tespiti ve kırılganlığın birinci basamakta yönetimi için katkı sağladığımızı düşünmekteyiz.

Anahtar sözcükler: Sonuçların yeniden üretilebilirliği; Kırılgan yaşlı; Yaşlanma; Türkiye 


\section{INTRODUCTION}

According to the World Health Organization (WHO), the geriatric population is estimated to increase to 1.2 billion by 2025 and to 2 billion by 2050 (1). It is believed that this ongoing increase in the elderly population may result in an increase in the frail elderly population and their problems (2). Age-related changes are associated with lifestyle and life events as well as genetic and environmental factors $(3,4)$. Therefore, while some elderly people may remain healthy, others are more frail and vulnerable to stress factors. Recently, the significance of the concept of frailty has substantially increased in studies on old age and the clinical care of the elderly (5).

The definition of frailty is debated; however, it may be defined as an age-related progressive decrease in physiological reserves and a related vulnerability to stressors that increases the risk of health-related adverse outcomes (6-8). Frailty is a dynamic condition that affects individuals who suffer from losses in one or more areas of human functioning (physical, psychological, and social) (9). The frail elderly are defined as individuals with increased vulnerability to external stressors due to age-related functional losses in the neuromuscular, metabolic, and immune systems; reduced mobility and strength; and nutritional disorders (10). Frail individuals are at a higher risk of clinically significant adverse events such as hospitalization, becoming care-dependent, falling, and mortality (3,5,7-9,11-14).

The assessment of frailty should be integrated into clinical practice as a part of routine care for the elderly (15). By doing so, a patient defined as frail can be referred for a more complete geriatric evaluation, and early interventions can be facilitated (12). Because early interventions can reverse frailty, screening and early diagnosis should be prioritized in primary care (12). Primary care doctors have a natural advantage when defining frailty owing to their patient-oriented approach, population-based evaluation role, and proximity and accessibility to the elderly (14). Therefore, primary care doctors require a valid and reliable method to initially diagnose elderly patients with frailty and then analyze and manage the problems detected (16).

In the elderly, frailty can be diagnosed early using appropriate screening methods. Scales developed worldwide must be adapted, and their validity and reliability must be evaluated being used in our country. In this context and based on current findings, the Tilburg Frailty Indicator (TFI) facilitates the screening for frailty in communitydwelling elderly people (5). Asserting that a practical screening tool was required to identify community-dwelling frail elderly people, Gobbens et al. developed the TFI in 2010 (9,13). Gobbens et al. aimed to evaluate frailty among the elderly by developing a scale to assess their physical, psychological, and social conditions based on the WHO definition of health as a complete state of physical, mental, and social well-being (13). The TFI is one of the few frailty scales regarded to be suitable for use in primary care owing to its simplicity and psychometric features that cover the biopsychosocial dimensions of frailty, and it is accepted as a valid and reliable instrument to screen for frailty $(12,14,17)$.

Developing a Turkish adaptation of the TFI and performing its validity-reliability assessment could make it easier for healthcare providers in Turkey to recognize frailty in the elderly and take preventive and therapeutic precautions. The main objective of the present study is to develop a Turkish adaptation of the TFI, which is globally accepted and widely used scale, and assess whether it is a valid and reliable instrument for the Turkish population. Hence, it will become easier to identify frailty and perform the necessary preventive and therapeutic interventions. 


\section{MATERIALS AND METHOD}

\section{Study design and participants}

The population of our study comprised individuals aged $>65$ years who applied to the Family Medicine Polyclinics and the Training Family Health Centers by a member of the medical faculty. As recommended for validity-reliability studies, the target sample size was 150, in order to represent at least 10 times the number of items. Before the study was conducted, ethical board approval was obtained from the Non-Interventional Clinical Studies Ethical Board on November 2, 2016 (decision number: 273). In our methodological study, data was collected using the TFI. After obtaining informed consent from the participants, surveys were administered using a face-to-face interview technique. The data were collected over a period of three months (01.01.2017 - 31.03.2017). Patients who were aged $<65$ years, did not want to participate in the study, provided incomplete answers to the questions, or were incapable of answering the questions were excluded from the study.

\section{The Tilburg Frailty Indicator}

The TFI comprises 25 questions divided into the following two parts: part $A$, containing 10 questions about illnesses and sociodemographic factors that determine frailty, and part B, containing 15 questions that evaluate three components of frailty (13). The physical component of the TFI comprises eight subitems: physical health, unwanted weight loss, difficulty in walking, difficulty in maintaining balance, poor hearing, visual difficulty, lack of strength in the hands, and physical tiredness. The psychological component of the TFI comprises four subitems: memory, depression, anxiety, and coping with problems. The social component of the TFI comprises three subitems: living alone, social relationships, and social support (13). Eleven items of the TFI have a double response category: "yes" and "no." Four items of the TFl have a triple response category: "yes," "sometimes," and "no" (13). The score ranges between 0-15 and scores $\geq 5$ indicate a positive finding of frailty (13).

\section{Language adaptation}

Process of language translation and adaptation complied with the recommendations of $\mathrm{WHO}$ (18). Two persons proficient in English and Turkish independently translated the TFI into Turkish. The translations were merged into a single Turkish form by a third person with proficiency in English and Turkish. The form created in Turkish was backtranslated into English by an additional person proficient in both English and Turkish who was not involved in the other stages of the translation. The final version of the form that was translated from Turkish to English was compared with the original version of the scale and reevaluated. The final Turkish adaptation of the scale was found to be consistent with the original scale. The completed translation of the form was finally evaluated by two experts in the field, and it acquired its final form.

\section{Statistical analysis}

The normality of the variables was evaluated using visual (histogram) and analytical (Kolmogorov-Smirnov test) methods. Among the data collected in the study, the average, mean, standard deviation, data range, and categorical data were expressed using descriptive methods such as ratio and percentage. The comparison of the presence or absence of differences between the averages of two independent groups was performed using the Student's t-test. Differences between groups compared by cross-tabulation were assessed using the chi-square or Fisher's exact tests where applicable. In more than two groups, one-way analysis of variance was used to compare variables identified by measurement.

The psychometric features of the scale were analyzed using the confirmatory approach, and 
known groups were analyzed by confirmatory factor analysis (CFA) for validity. To test the agreement of the model tested with the data analyzed, several values were calculated including the chi-square; comparative fit index (CFI) of the model being tested; the standardized root mean square residual (SRMR), which gives the average of the differences between the explained and observed covariances; the root mean square error of approximation (RMSEA); the goodness-of-fit index (GFI); and the adjusted goodness-of-fit index (AGFI). The values of goodness of fit of the confirmatory factor analysis model were evaluated using the model of Schermelleh-Engel et al. and these values are given in Table 4 (19). The Cronbach's alpha reliability coefficient was used for the reliability of the Turkish adaptation of the TFI. The internal consistency coefficient for reliability was assessed using the Kuder-Richardson-21 Formula coefficient (KR-21). In statistical group analyses, $\mathrm{p}<0.05$ was regarded as significant. The SPSS Statistics for Windows, version 23 (IBM Corp., Armonk, NY, USA) and LISREL 8.5 statistics package programs (Scientific Software, Mooresville, IN, USA) were used for the analyses.

\section{RESULTS}

The continuous data followed a normaldistribution, hence parametric statistical methods were used during analysis as appropriate.

\section{Participant characteristics}

This study included 271 individuals with a median age of 71 years (range $=65-90$ years) and $50.6 \%$ males ( $n=137)$. Among the participants, $70.8 \%(n=192)$ were married, and the education level was equivalent to or under primary education [51.3\% $(n=139)]$. The frailty scores of the participants were identified as $2.35 \pm 2.04,1.14 \pm 1.21,1.06 \pm 0.75$, and $4.56 \pm 3.09$ (physical, psychological, social, and total, respectively) (Table 1).

There were no gender differences between the four items that comprise the frailty components. However, women experienced more difficulty in walking, maintaining balance, vision, and lack of hand strength. Women also struggled more than men with tiredness, memory problems, depression, loneliness, and social support. It was established that men felt physically healthier than women and better coped with problems (Table 2).

\section{Reliability analysis}

Reliability was calculated for the total TFI score and the three subcomponents of the TFI. The total value of Cronbach's alpha reliability coefficient for TFI was found to be 0.758 , with 0.727 for the physical component, 0.675 for the psychological component, and 0.049 for the social component. The internal consistency coefficient was calculated in the reliability analysis of the scale. The KR-21 reliability coefficient obtained in the subdimensions of the scale was identified as 0.758 for the entire scale. The corrected item correlations for the TFI items are presented in Table 3. The correlations between each item and their dimension total scores are presented in Table 3 and each item showed statistically significant correlation within their dimension.

\section{Validity analysis}

In the exploratory factor analysis, CFA was performed to identify whether or not the threefactor model was verified (Figure 1).

The good adjustment values obtained in the CFA are 1.82 for the chi-square/degree of freedom, 0.054 for the RMSEA, and 0.064 for the SRMR. The CFI value was identified as 0.950, the GFI value as 0.928, and the AGFI value as 0.901. Our CFI and GFI values were close to values of good agreement. The values obtained were at least acceptable for all parameters and the summary of good agreement findings obtained by CFA showed that the scale can conceptually define the construct it was designed to measure at a good level (Table 4). 
Table 1. The characteristics of the participants.

\begin{tabular}{|c|c|c|c|c|c|c|c|c|}
\hline \multirow{2}{*}{ Characteristics } & \multicolumn{2}{|r|}{ Male } & \multicolumn{2}{|c|}{ Female } & \multicolumn{2}{|r|}{ Total } & \multicolumn{2}{|c|}{ Statistical analysis } \\
\hline & $\mathrm{n}$ & $\%$ & $\mathrm{n}$ & $\%$ & $\mathrm{n}$ & $\%$ & $x^{2}$ & $p$ \\
\hline \multicolumn{9}{|l|}{ Age } \\
\hline $65-69$ & 44 & 32.1 & 61 & 45.5 & 105 & 38.7 & \multirow{3}{*}{5.83} & \multirow{3}{*}{0.054} \\
\hline $70-74$ & 41 & 29.9 & 37 & 27.6 & 78 & 28.8 & & \\
\hline$\geq 75$ & 52 & 38.0 & 36 & 26.9 & 88 & 32.5 & & \\
\hline \multicolumn{9}{|l|}{ Marital status } \\
\hline Married/Living together & 126 & 92.0 & 66 & 49.3 & 192 & 70.8 & \multirow{3}{*}{63.23} & \multirow{3}{*}{$<0.001^{\star * \star}$} \\
\hline Single/Separated & 3 & 2.2 & 3 & 2.2 & 6 & 2.2 & & \\
\hline Widow/widower & 8 & 5.8 & 65 & 48.5 & 73 & 26.9 & & \\
\hline \multicolumn{9}{|l|}{ Education level } \\
\hline Primary school or lower (Low) & 48 & 35.0 & 96 & 71.6 & 144 & 53.1 & \multirow{3}{*}{36.72} & \multirow{3}{*}{$<0.001^{\star * x}$} \\
\hline $\begin{array}{l}\text { High school or equivalent } \\
\text { schools (Moderate) }\end{array}$ & 49 & 35.8 & 23 & 17.2 & 72 & 26.6 & & \\
\hline $\begin{array}{l}\text { College/Faculty or higher } \\
\text { (Advanced) }\end{array}$ & 40 & 29.2 & 15 & 11.2 & 55 & 20.3 & & \\
\hline \multicolumn{9}{|l|}{ Income } \\
\hline 1500 TL or under (Low) & 28 & 20.4 & 73 & 54.5 & 101 & 37.3 & \multirow{3}{*}{37.12} & \multirow{3}{*}{$<0.001 * * *$} \\
\hline 1501 - 3500 TL (Moderate) & 70 & 51.1 & 48 & 35.8 & 118 & 43.5 & & \\
\hline 3501 TL or higher (High) & 39 & 28.5 & 13 & 9.7 & 52 & 19.2 & & \\
\hline \multicolumn{9}{|l|}{ Health perception } \\
\hline Healthy & 79 & 57.7 & 49 & 36.6 & 128 & 47.2 & \multirow{3}{*}{16.58} & \multirow{3}{*}{$<0.001^{\star \star \star}$} \\
\hline Nor health nor unhealthy & 53 & 38.7 & 66 & 49.3 & 119 & 43.9 & & \\
\hline Unhealthy & 5 & 3.6 & 19 & 14.2 & 24 & 8.9 & & \\
\hline & mean & sd & mean & sd & mean & sd & & $\mathrm{p}$ \\
\hline TFI physical component & 1.69 & 1.88 & 3.02 & 1.99 & 2.35 & 2.04 & & $<0.001^{\star \star *}$ \\
\hline TFI psychological component & 0.78 & 1.01 & 1.51 & 1.27 & 1.14 & 1.21 & & $<0.001^{\star * *}$ \\
\hline TFI social component & 0.89 & 0.67 & 1.23 & 0.79 & 1.06 & 0.75 & & $<0.001^{\star \star *}$ \\
\hline TFI total score & 3.37 & 2.63 & 5.77 & 3.06 & 4.56 & 3.09 & & $<0.001^{\star * \star}$ \\
\hline
\end{tabular}

${ }^{*} p<0.05,{ }^{* *} p<0.01,{ }^{* \star *} p<0.001$

Construct Validity was assessed by correlation between the TFI total score and other frailty measures. The Timed Up \& Go (TUG) test walking speed showed stronger correlation 0.600 with physical domain and weaker correlations with psychological and social components $(r=0.294$ and $r=0.123$ respectively). Poor self-rated health $(r=0.372, p<0.001)$, number of chronic diseases $(r=0.193, p=0.001)$, and quality of life $(r=0.419$, $p<0.001$ ) were correlated with TFI score. Individuals with chronic disease had significantly higher TFI scores compared to their health counterparts (4.65 \pm 3.13 vs. $3.00 \pm 1.73, p=0.003)$. 
Table 2. The assessment of TFI items with respect to gender.

\begin{tabular}{|c|c|c|c|c|c|c|c|c|}
\hline \multirow{3}{*}{ TFI items } & \multicolumn{2}{|c|}{ Male } & \multicolumn{2}{|c|}{ Female } & \multicolumn{2}{|c|}{ Total } & \multicolumn{2}{|c|}{ Statistical analysis } \\
\hline & Yes & No & Yes & No & Yes & No & & \\
\hline & $n(\%)$ & $n(\%)$ & $\mathrm{n}(\%)$ & $\mathrm{n}(\%)$ & $n(\%)$ & $\mathrm{n}(\%)$ & $x^{2}$ & $p$ \\
\hline \multicolumn{9}{|l|}{ Physical components } \\
\hline $\begin{array}{l}\text { 11. Do you feel physically } \\
\text { healthy? }\end{array}$ & $\begin{array}{c}104 \\
(75.9)\end{array}$ & $\begin{array}{c}33 \\
(24.1)\end{array}$ & $\begin{array}{c}62 \\
(46.3)\end{array}$ & $\begin{array}{c}72 \\
(53.7)\end{array}$ & $\begin{array}{c}166 \\
(61.3)\end{array}$ & $\begin{array}{c}105 \\
(38.7)\end{array}$ & 25.08 & $<0.001^{\star \star *}$ \\
\hline $\begin{array}{l}\text { 12. Have you lost a lot of } \\
\text { weight recently without } \\
\text { wishing to do so? }\end{array}$ & $\begin{array}{c}7 \\
(5.1) \\
\end{array}$ & $\begin{array}{c}130 \\
(94.9)\end{array}$ & $\begin{array}{c}9 \\
(6.7)\end{array}$ & $\begin{array}{c}125 \\
(93.3) \\
\end{array}$ & $16(5.9)$ & $\begin{array}{c}255 \\
(94.1)\end{array}$ & 0.31 & 0.575 \\
\hline 13. Difficulty in walking? & $\begin{array}{c}48 \\
(35.0) \\
\end{array}$ & $\begin{array}{c}89 \\
(65.0) \\
\end{array}$ & $\begin{array}{c}88 \\
(65.7) \\
\end{array}$ & $\begin{array}{c}46 \\
(34.3) \\
\end{array}$ & $\begin{array}{c}136 \\
(50.2) \\
\end{array}$ & $\begin{array}{c}135 \\
(49.8) \\
\end{array}$ & 25.43 & $<0.001^{\star \star \star}$ \\
\hline $\begin{array}{l}\text { 14. Difficulty maintaining } \\
\text { your balance? }\end{array}$ & $\begin{array}{c}27 \\
(19.7)\end{array}$ & $\begin{array}{c}110 \\
(80.3)\end{array}$ & $\begin{array}{c}56 \\
(41.8)\end{array}$ & $\begin{array}{c}78 \\
(58.2)\end{array}$ & $\begin{array}{c}83 \\
(30.6)\end{array}$ & $\begin{array}{c}188 \\
(69.4)\end{array}$ & 15.54 & $<0.001^{\star * *}$ \\
\hline 15. Poor hearing? & $\begin{array}{c}42 \\
(30.7)\end{array}$ & $\begin{array}{c}95 \\
(69.3) \\
\end{array}$ & $\begin{array}{c}37 \\
(27.6) \\
\end{array}$ & $\begin{array}{c}97 \\
(72.4) \\
\end{array}$ & $\begin{array}{c}79 \\
(29.2)\end{array}$ & $\begin{array}{c}192 \\
(70.8)\end{array}$ & 0.30 & 0.581 \\
\hline 16. Poor vision? & $\begin{array}{c}25 \\
(18.2) \\
\end{array}$ & $\begin{array}{c}112 \\
(81.8) \\
\end{array}$ & $\begin{array}{c}38 \\
(28.4) \\
\end{array}$ & $\begin{array}{c}96 \\
(71.6)\end{array}$ & $\begin{array}{c}63 \\
(23.2) \\
\end{array}$ & $\begin{array}{c}208 \\
(76.8)\end{array}$ & 3.88 & $0.049^{*}$ \\
\hline $\begin{array}{l}\text { 17. Lack of strength in your } \\
\text { hands? }\end{array}$ & $11(8.0)$ & $\begin{array}{c}126 \\
(92.0)\end{array}$ & $\begin{array}{c}33 \\
(24.6)\end{array}$ & $\begin{array}{c}101 \\
(75.4)\end{array}$ & $\begin{array}{c}44 \\
(16.2)\end{array}$ & $\begin{array}{c}227 \\
(83.8)\end{array}$ & 13.72 & $<0.001^{\star * *}$ \\
\hline 18. Physical tiredness? & $\begin{array}{c}39 \\
(28.5)\end{array}$ & $\begin{array}{c}98 \\
(71.5)\end{array}$ & $\begin{array}{c}72 \\
(53.7)\end{array}$ & $\begin{array}{c}62 \\
(46.3)\end{array}$ & $\begin{array}{c}111 \\
(41.0)\end{array}$ & $\begin{array}{c}160 \\
(59.0)\end{array}$ & 17.88 & $<0.001^{\star \star \star}$ \\
\hline
\end{tabular}

\section{Psychological components}

19. Do you have problems with your memory?

$11(8.0)$

$\begin{array}{lllll}126 & 26 & 108 & 37 & 234\end{array}$

$(92.0) \quad(19.4) \quad(80.6) \quad(13.7) \quad(86.3)$

7.43

$0.006^{\star *}$

20. Have you felt down 37 during the last month?

$\begin{array}{llllll}37 & 100 & 84 & 50 & 121 & 150\end{array}$

(27.0) (73.0)

$(62.7)$

(37.3)

(44.6)

150

34.89

$<0.001 * * *$

21. Have you felt nervous or anxious during the last month?

$\begin{array}{cccccccc}52 & 85 & 66 & 68 & 118 & 153 & 3.51 & 0.061 \\ (38.0) & (62.0) & (49.3) & (50.7) & (43.5) & (56.3) & \end{array}$

22. Are you able to cope with problems well?

$\begin{array}{cccc}130 & 7 & 107 & 27 \\ (94.9) & (5.1) & (79.9) & (20.1)\end{array}$

237

$237 \quad 34$

$\begin{array}{cc}237 & 34 \\ (87.5) & (12.5)\end{array}$

13.96

$<0.001^{\star \star \star}$

\section{Social components}

23. Do you live alone?

24. Do you sometimes miss having people around you?

\begin{tabular}{cccccccc}
7 & 130 & 36 & 98 & 43 & 228 & 24.01 & $<0.001^{\star * *}$ \\
$(5.1)$ & $(94.9)$ & $(26.9)$ & $(73.1)$ & $(15.9)$ & $(84.1)$ & & \\
81 & 56 & 95 & 39 & 176 & 95 & 4.12 & $0.042 *$ \\
$(59.1)$ & $(40.9)$ & $(70.9)$ & $(29.1)$ & $(64.9)$ & $(35.1)$ & & \\
\hline
\end{tabular}

25. Do you receive enough support from other people?

$\begin{array}{cccccccc}102 & 35 & 99 & 35 & 201 & 70 & 0.01 & 0.914 \\ (74.5) & (25.5) & (73.9) & (26.1) & (74.2) & (25.8) & 0.01 & \end{array}$

${ }^{*} \mathrm{p}<0.05,{ }^{* *} \mathrm{p}<0.01,{ }^{* * *} \mathrm{p}<0.001$ 


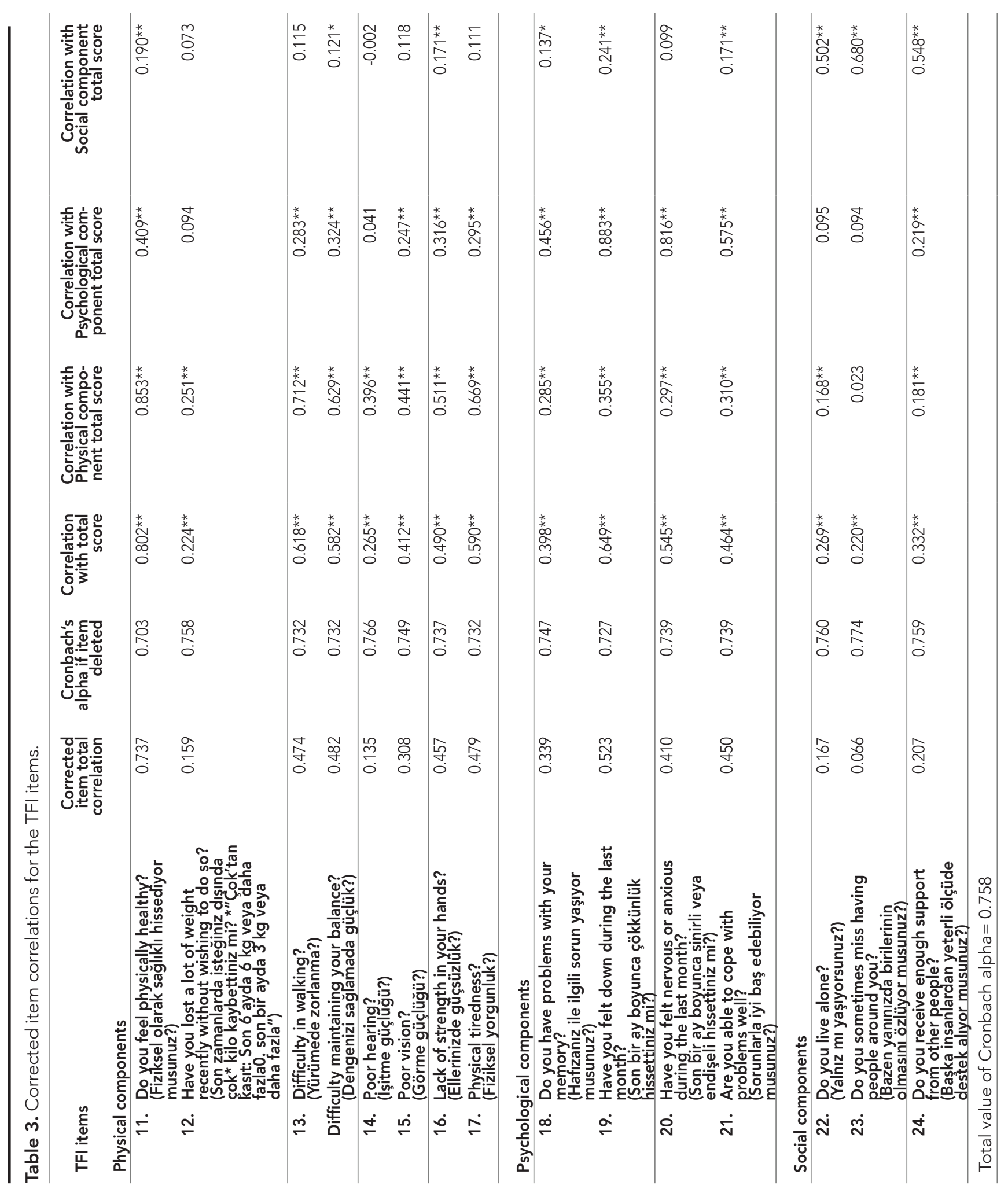




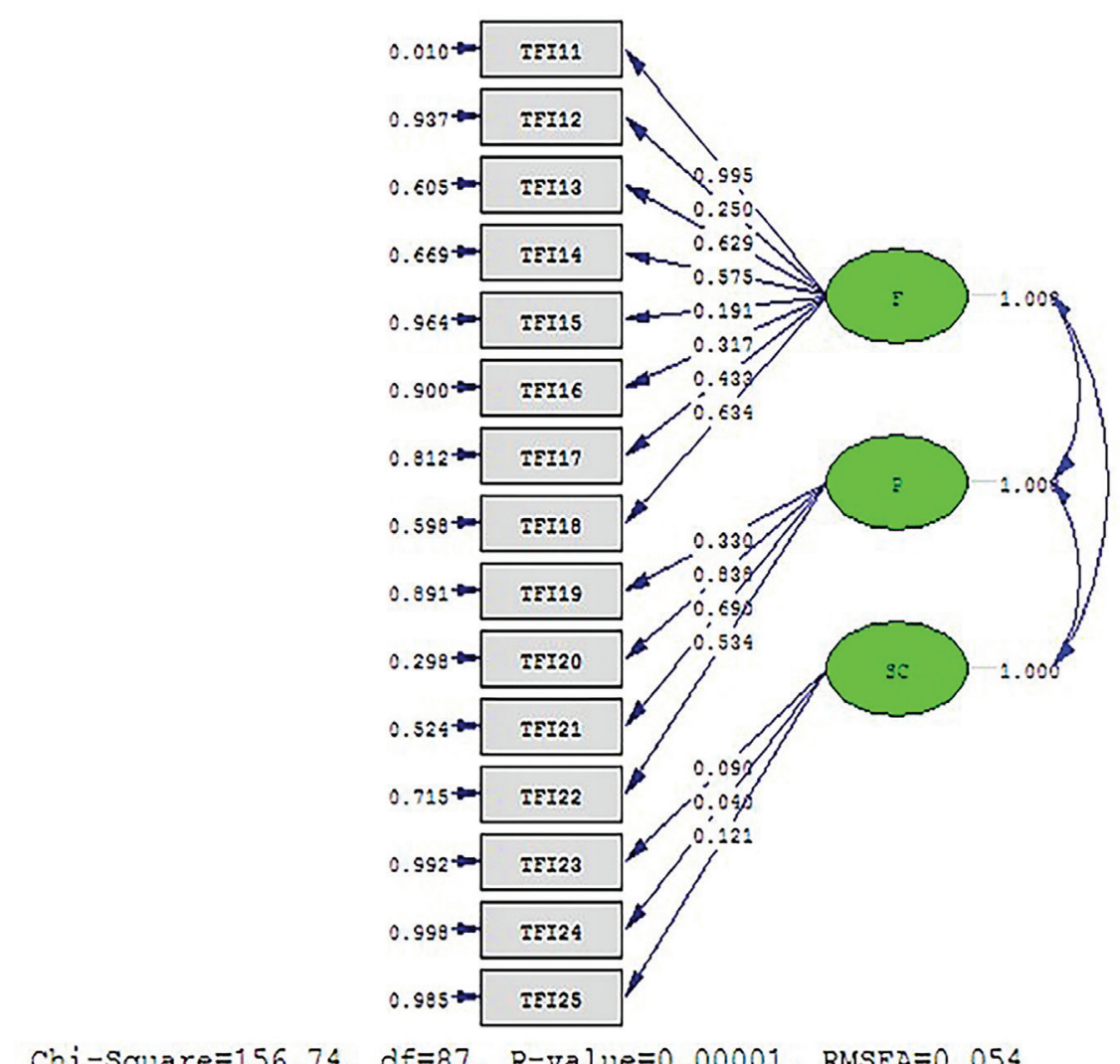

$\mathrm{TFI}=$ Tilburg Frailty Indicator, $\mathrm{F}=\mathrm{TFI}$ physical component, $\mathrm{P}=\mathrm{TFI}$ psychological component, $\mathrm{SC}=\mathrm{TFI}$ social component

Figure 1. The pathway of the standardized values of the items of the Tilburg Frailty Scale.

Table 4. The confirmatory factor analysis models of the Tilburg Frailty Indicator.

\begin{tabular}{lcccc}
\hline Fit measure & Good fit & Acceptable fit & Model fit & Interpretation \\
\hline $\mathbf{2}$ /df & $0 \leq \chi 2 / \mathrm{df} \leq 2$ & $2 \leq \chi 2 / \mathrm{df} \leq 3$ & 1.82 & Good fit \\
\hline RMSEA & $0 \leq \mathrm{RMSEA} \leq 0.05$ & $0.05 \leq \mathrm{RMSEA} \leq 0.08$ & 0.054 & Acceptable fit \\
\hline SRMR & $0 \leq \mathrm{SRMR} \leq 0.05$ & $0.05<\mathrm{SRMR} \leq .10$ & 0.064 & Acceptable fit \\
\hline CFI & $0.97 \leq \mathrm{CFI} \leq 1.00$ & $0.95 \leq \mathrm{CFI}<0.97$ & 0.950 & Acceptable fit \\
\hline GFI & $0.95 \leq \mathrm{GFI} \leq 1.00$ & $0.90 \leq \mathrm{GFI}<0.95$ & 0.928 & Acceptable fit \\
\hline AGFI & $0.90 \leq \mathrm{AGFI} \leq 1.00$ & $0.85 \leq \mathrm{AGFI}<0.90$ & 0.901 & Good fit \\
\hline AGFI Adjus
\end{tabular}

$\overline{\mathrm{AGFI}}=$ Adjusted Goodness-of-Fit-Index, CFI = Comparative Fit Index, GFI = Goodness-of-Fit Index, RMSEA = Root Mean Square Error of Approximation, SRMR = Standardized Root Mean Square Residual. 


\section{DISCUSSION}

Our findings revealed that the Turkish version of the TFI is satisfactory with respect to reliability, the internal consistency coefficient, and construct validity. The internal consistency for the total TFI score was at acceptable levels but the Cronbach's alpha reliability coefficient and adjusted item total correlations showed that the internal consistency reliability coefficients were low for some of the subitems of the TFI, particularly those of the social component. These results are similar to the results obtained for the original version of the TFI and other translated versions $(5,13,20)$. CFA of the scale revealed that the RMSEA and SRMR values were $<0.08$ and that the CFI, GFI, and AGFI values were $>0.90$. The CFA goodness-of-fit findings revealed that the scale can conceptually define the construct that it aimed to assess at a good level indicating that the scale is satisfactory with respect to construct validity.

In our study, the total TFI score was 4.56. The total TFI score and the average score of all subdimensions were statistically significantly higher in women than in men $(p<0.001)$. These results were similar to those of other validity-reliability studies of the TFI performed worldwide $(17,20)$. In the original study, Gobbens et al. developed the TFI with two groups: 245 and 234 people with average ages of 80.3 and 80.2 years with a total TFI score of $4.7 / 4.7$, physical score of 2.6/2.5, psychological component score of 0.9/1.0, and social component score of 1.2/1.3 (13). In our study, similar score averages were found.

In studies that set the TFI cutoff point for frailty at 5 , the ratio of frailty was $44.6 \%$ in the Italian sample with an average age of 73.4 years, $47.1 \%$ in the Dutch sample with an average age of 80.3 years, $40 \%$ in the Polish sample with an average age of 68.2 years, $35.6 \%$ and $31.7 \%$ in two Brazilian samples with average ages of 69.8 and 71.3 years, and $41.4 \%$ in the German sample with an average age of 75.3 years $(13,17,20-23)$. In the Portuguese sample that set the cutoff point for frailty at 6 , the average age was 79.2 years, and frailty was identified in $54.8 \%$ of the sample population (5). In our study, the cutoff point was set at 5 , the average age was 72.4 years, and the ratio of frailty was $45.4 \%$. The ratio of frailty identified using the TFI was similar to ratios identified in other European countries. Although there are differences between countries in the total TFI average scores or the average ages of the participants, in most European countries the ratios of frailty identified using the TFI are similar and independent of these factors. The frequency of frailty is similar in countries such as Holland, Italy, Poland, and Germany, where per capita health expenditure is higher than that in Turkey, which indicates that frailty is associated not only with the socioeconomic development of countries but also with many other factors.

The review of the internal consistency assessments of the TFI subdimensions revealed that that the internal consistency values for the physical and psychological components were good (Cronbach's alpha $=0.727$ and 0.675 , respectively), but the value for the social component was unsatisfactory (Cronbach's alpha=0.049). Gobbens et al. identified the Cronbach's alpha values for the total TFI as 0.73 , for the physical component as 0.70 , for the psychological component as 0.63 , and for the social component as 0.34 , and these results are similar to those of our study (13). Our findings were similar to those of the study by Gobbens et al as well as validity-reliability studies conducted in other countries, and the total Cronbach's alpha value for the TFI varied between 0.66 and 0.78 , for the physical component varied between 0.57 and 0.79 , for the social component varied between 0.43 and 0.53 , and for the TFI social component varied between 0.36 and $0.49(5,17,20,22,23)$. In other validity-reliability studies of the TFI, the internal consistency of the social component was low, which is similar to the results of our study. This suggests that adding other items to the social component may increase the internal consistency coefficient but could complicate the simple, rapid, and easy application of the scale. 
In a study conducted in Holland that included 532 people, the average age was 77.2 years, the ratio of frailty based on the TFI was $40.2 \%$, and the total Cronbach's alpha value was 0.73 (21). The corrected item total correlations varied between 0.18 and 0.58 (21). The corrected item total correlations varied between 0.12 and 0.52 in the Polish validityreliability study, and it was stated that these values were $>0.30$ for all items in the Brazilian validity and reliability study $(22,23)$. The German validityreliability study showed that the corrected item total correlations varied between -0.06 and 0.57 and that the "coping with problems" item exhibited negative correlation (17). In our study, the corrected item total correlations varied between 0.06 and 0.73. The differences between corrected item total correlations could potentially be attributed to sociocultural differences between countries. The low values of the correlation coefficients of some items on the scale did not affect the overall value of the Cronbach's alpha reliability coefficient. Therefore, we concluded that this did not influence the frailty score that the scale aims to measure.

\section{Limitations}

The sample was selected solely from communitydwelling elderly people, and further comprehensive studies should be performed using the TFI in elderly people in hospitals and residing in nursing homes. Long-term studies are required to evaluate the prediction of the mid- and long-term adverse effects of frailty and each subcomponent. Studies that evaluate the psychometric features of the TFI are required to obtain better results for the Turkish version of the TFI and identify the adequate cutoff point for use in Turkey.

Some of the correlation coefficent values and internal consistency were low especially for social domain. The first reason might be due to the fact that the measure did not consist of closely related components and tried to explain most important elements of frailty and its domains by using few questions. Another reason is the social domain contains only three items hence it is not surprising that the correlation of these three variables provided low values. It is possible to increase internal consistency by adding other indicators of social frailty in the future. However, the researchers should use and interpret the social dimension scores with caution when they want to use the scale.

In conclusion, it has been established that the Turkish adaptation of the TFI is a valid and reliable instrument. This self-reported scale requires minimal time to administer, is validated for use in primary care, and is a valuable screening instrument. This study is the first step in Turkey toward adopting the use of the TFI which is a multidimensional, specific, cost saving, and easily administered scale applicable for both clinical and scientific purposes. Finally, we believe that our findings have contributed to the early detection of health-related problems in the elderly and the management of frailty in primary care in our country by developing the Turkish version of the TFI. It is a simple and invaluable screening tool that effectively identifies frailty in the elderly using a multidimensional perspective and facilitates effective interventions to prevent adverse outcomes.

\section{Acknowledgements}

We owe thanks to Dr Elif Keskin-Arslan for help in data entry. We would like to acknowledge Dr Hakan Baydur from Celal Bayar University Faculty of Medical Sciences for his support during statistical analysis and their interpretation.

\section{Conflict of interest}

No conflict of interest was declared by the authors.

\section{Financial disclosure}

The authors declared that this study has received no financial support. 


\section{REFERENCES}

1. World Health Organization launches new initiative to address the health needs of a rapidly ageing population. [Internet] Available from: http://www. who.int/mediacentre/news/releases/2004/pr60/en/. Accessed: 19.05.2017.

2. Aslan D, Keskin C. Public Health Aspect of "Frail" Elderly Concern. Journal of Continuing Medical Education 2015 Mar-Apr;24(2):73-8. (in Turkish).

3. Coelho T, Paúl C, Gobbens RJJ, Fernandes L. Determinants of frailty: the added value of assessing medication. Front Aging Neurosci 2015 Apr 21;7(56):1-8. (PMID:25954195).

4. Clegg A, Young J, lliffe S, Rikkert MO, Rockwood K. Frailty in elderly people. Lancet 2013 Mar;381:75262. (PMID:23395245).

5. Coelho T, Santos R, Paúl C, Gobbens RJ, Fernandes L. Portuguese version of the Tilburg Frailty Indicator: Transcultural adaptation and psychometric validation. Geriatr Gerontol Int 2015 Aug;15(8):95160. (PMID:25255891).

6. World Health Organization. Chapter 3: Health in Older Age. World Report on Ageing and Health. Geneva 2015, pp 43-88. [Internet] Available from: http://www.who.int/life-course/publications/2015ageing-report/en/. Accessed: 19.05.2017.

7. Walston JD. Frailty. UpToDate 2017, pp 1-45. [Internet] Available from: https://www.uptodate. com/contents/frailty. Accessed: 19.02.2017.

8. Fried LP, Tangen CM, Walston J, et al. Frailty in older adults: Evidence for a phenotype. J Gerontol A Biol Sci Med Sci 2001;56(3):146-64. (PMID:11253156).

9. Gobbens RJJ, van Assen MALM, Luijkx KG, WijnenSponselee MT, Schols JMGA. Determinants of Frailty. J Am Med Dir Assoc 2010 Jun;11(5):356-64. (PMID:20511103).

10. Şahin S, Cankurtaran M. Geriatrics Syndromes. Ege J Med 2010;49(3):31-7. (in Turkish).

11. Soysal P, Stubbs B, Lucato $P$, et al. Inflammation and frailty in the elderly: A systematic review and meta-analysis. Ageing Res Rev 2016 Nov;31:1-8. (PMID:27592340).

12. Pialoux T, Goyard J, Lesourd B. Screening tools for frailty in primary health care: A systematic review. Geriatr Gerontol Int 2012 Apr;12(2):189-97. (PMID:22233158).

13. Gobbens RJJ, van Assen MALM, Luijkx KG, WijnenSponselee MT, Schols JMGA. The Tilburg Frailty Indicator: Psychometric Properties. J Am Med Dir Assoc 2010 Jun;11(5):344-55. (PMID:20511102).
14. Vergara I, Rivas-Ruiz F, Vrotsou K, et al. Validation and comparison of instruments to identify frail patientes in primary care settings: Study protocol. BMC Health Serv Res 2016;16(1):354. (PMID:27492438).

15. Dent E, Kowal P, HoogendijkEO. Frailty measurement in research and clinical practice: A review. Eur J Intern Med 2016 Jun;31:3-10. (PMID:27039014).

16. van Kempen JA, Melis RJ, Perry M, Schers HJ, Rikkert MG. Diagnosis of Frailty after a Comprehensive Geriatric Assessment: Differences between Family Physicians and Geriatricians. J Am Board Fam Med 2015 Mar-Apr;28(2):240-8. (PMID:25748765).

17. Freitag S, Schmidt S, Gobbens RJJ. Tilburg frailty indicator: German translation and psychometric testing. Z Gerontol Geriatr 2016 Feb 8;49(2):86-93. (PMID:25953342).

18. WHO | Process of translation and adaptation of instruments. [Internet] Available from: http:// www.who.int/substance_abuse/research_tools/ translation/en/\#. Accessed:08.03.2018.

19. Schermelleh-Engel $K$, Moosbrugger $H$, Müller $H$. Evaluating the Fit of Structural Equation Models: Tests of Significance and Descriptive Goodnessof-Fit Measures. Methods Psychol Res Online 2003;8(2):23-74.

20. Mulasso A, Roppolo M, Gobbens RJJ, Rabaglietti E. The Italian Version of the Tilburg Frailty Indicator: Analysis of Psychometric Properties. Res Aging 2016 Nov;38(8):842-63. (PMID:26377805).

21. Metzelthin SF, Daniëls $R$, van Rossum E, de Witte $L$, van den Heuvel WJ, Kempen GI. The psychometric properties of three self-report screening instruments for identifying frail older people in the community. BMC Public Health 2010 Mar;10(1):176. (PMID:20353611).

22. Uchmanowicz I, Gobbens R, Jankowska-Polanska B, Loboz-Rudnicka M, Manulik S, Loboz-Grudzien K. Cross-cultural adaptation and reliability testing of the Tilburg Frailty Indicator for optimizing care of Polish patients with frailty syndrome. Clin Interv Aging 2014 Jun;9:997-1001. (PMID: 25028543).

23. Santiago LM, Luz LL, Mattos IE, Gobbens RJJ, van Assen MA. Psychometric properties of the Brazilian version of the Tilburg frailty indicator (TFI). Arch Gerontol Geriatr 2013 Jul-Aug;57(1):39-45. (PMID:23538005). 